Original Research Article

\title{
Pentobarbitone-induced sleeping time and sub-acute toxicity studies of Trichilia monadelpha aqueous extract
}

\author{
George Owusu $^{1,3}$, Meshack Antwi-Adjei ${ }^{2,3}$, Isaac T. Henneh ${ }^{2,3} *$
}

\begin{abstract}
${ }^{1}$ Department of Pharmacology, School of Medicine, University for Development Studies,

Tamale, Ghana

${ }^{2}$ Department of Pharmacology, School of Medical Science, University for Development Studies, Tamale, Ghana ${ }^{3}$ Department of Pharmacology, , Faculty of Pharmacy and Pharmaceutical Sciences, Kwame Nkrumah University of Science and Technology, Kumasi, Ghana
\end{abstract}

Received: 20 September 2016 Accepted: 20 October 2016

\section{*Correspondence to: \\ Mr. Isaac T. Henneh, \\ Email: i.t.henneh@ \\ uccsms.edu.gh}

Copyright: (c) the author(s), publisher and licensee Medip Academy. This is an openaccess article distributed under the terms of the Creative Commons Attribution NonCommercial License, which permits unrestricted noncommercial use, distribution, and reproduction in any medium, provided the original work is properly cited.

\section{ABSTRACT}

Background: Trichilia monadelpha is used either alone or in combination with other plants to treat many diseases in West Africa. Earlier, the antiinflammatory, analgesic and anti-parasitic effects of the plant have been investigated to confirm its folkloric use. The current study is aimed at investigating the sub-acute toxicity profile as well as hypno-sedative effect of the Trichilia monadelpha aqueous extract (TAE).

Methods: For the pentobarbitone-induced sleeping test, rats (150-200 g, n=5) were pre-treated with TAE $(100,300$ and $1000 \mathrm{mg} / \mathrm{kg}$, p.o. $)$ or distilled water (control group) 30 minutes before they were challenged with Pentobarbitone Sodium $(50 \mathrm{mg} / \mathrm{kg}$ body weight, i.p). Sleeping time of each animal was recorded and analysed. In the sub-acute toxicity test, rats were treated daily either TAE (30, 100 and $1000 \mathrm{mg} / \mathrm{kg}$ ) or water (control group) for two weeks after which the animals were sacrificed. Blood samples were collected for haematological and biochemical analyses. Specific organs were then removed and weighed immediately.

Results: The pentobarbitone-induced sleeping test resulted in a significant and dose-dependent increase in the duration of sleep of the rats. There were however no significant changes in the relative weight of vital organs of the control and TAE treated groups. Similarly, there were no significant differences in haematological and biochemical parameters between control and TAE treated groups.

Conclusions: TAE significantly and dose-dependently increased the duration of pentobarbitone-induced sleeping time in rats. TAE showed no significant changes in the relative weight of the vital organs, haematological and biochemical parameters.

Keywords: Trichilia monadelpha, Pentobarbitone, Hypno-sedative, Sub-acute toxicity

\section{INTRODUCTION}

Trichilia monadelpha (Thonn) JJ De Wilde (fam. Meliaceae) is a medium-sized tree that grows up to $20 \mathrm{~m}$ high in the tropical rain forest in West Africa. Different parts of the plant are used either alone or in combination with other plants for treatment of many diseases in West Africa. ${ }^{1}$

Previously, the inhibitory effects of the aqueous, hydroethanol and petroleum ether extracts of the stem bark of the plant in carrageenan-induced paw oedema in 7-day- old chicks and Complete Fruend's adjuvant-induced arthritis in rats has been reported. ${ }^{2}$ Also, the analgesic effect of the hydro-ethanol, petroleum ether and ethyl acetate extracts of the stem bark of the plant has been earlier reported. ${ }^{3}$ Again, the antioxidant potential and phytochemical constituents of the stem bark extracts of the plant have been evaluated. ${ }^{4}$ Moreover, the plant has been reported to possess antiplasmodial and antitrypanosomal properties. ${ }^{5}$ Despite the numerous activities of the plant reported in literature, there is no valid scientific data on its hypno-sedative effects and toxicity profile. 
Since the aqueous extract is mostly used in traditional medicine, it is imperative that a scientific assessment of toxicity profile as well as the hypno-sedative effect of the aqueous extract is carried out.

\section{METHODS}

\section{Plant collection}

Stem bark of Trichilia monadelpha was collected from Bomaa in the Brong Ahafo region of Ghana. It was authenticated by the curator of the herbarium unit of Department of Herbal Medicine, School of Pharmacy and Pharmaceutical Sciences, Kwame Nkrumah University of Science and Technology (KNUST), Kumasi, Ghana. The plant material was chopped into pieces and dried under room temperature for seven days.

\section{Extraction}

The dried pieces were pulverised into a coarse powder with a hammer mill. Six hundred grams $(600 \mathrm{~g})$ of the powder was infused with 3.0L of water and warmed for 60 minutes at $90^{\circ} \mathrm{C}$. The infusion was filtered to obtain a dark-brown filtrate which was evaporated over a hot water-bath and later in oven at $55^{\circ} \mathrm{C}$ until a constant weight was obtained. This was finally cooled in a desiccator to yield a dark-brown solid Trichilia aqueous extract (referred to as TAE) and the final yield was $16.54 \%$. The extract was reconstituted as an emulsion in $2 \%$ tragacanth mucilage.

\section{Chemicals}

Pentobarbitone sodium was obtained from British Drug House, Poole, England.

\section{Animals}

Male Spraque-Dawley rats weighing between 150-200g were purchased from Noguchi memorial Institute for Medical research, Accra, Ghana. The animals were kept in stainless steel cages $(34 \mathrm{~cm} \times 47 \mathrm{~cm} \times 18 \mathrm{~cm})$ in the animal house of Department of Pharmacology, KNUST. Animals were maintained under laboratory conditions (temperature $24-25^{\circ} \mathrm{C}, 12$-hour light-dark cycle) and fed with commercial pellet diet (GAFCO, Tema, Ghana) and water ad libitum. All experiments were conducted in accordance with the National Institute of Health Guidelines for the Care and Use of Laboratory Animals (NIH Publication No. 85-23, 1985, revised 1996). All protocols used were approved by the Departmental Ethics Committee.

\section{Phytochemical screening}

The aqueous extract was screened using simple qualitative methods previously described by Trease and Evans and Sofowora. 6,7

\section{Pentobarbitone-induced sleeping test}

Sprague-Dawley rats (150-200 g, n=5) were categorized into 10 groups. Initially, a preliminary study was conducted where groups (I, II and III) rats were injected with 50,75 and $100 \mathrm{mg} / \mathrm{kg}$ (i.p) pentobarbitone sodium to determine its minimal hypno-sedative dosage and onset of action respectively. Groups (IV, V and VI) were treated with 100, 300 and $1000 \mathrm{mg} / \mathrm{kg}$ (p.o.) of TAE without pentobarbitone challenge to evaluate its ability to induce sleep. Latency period of 90 minutes was allowed and duration of sleep noted. From the results obtained, a dose of $50 \mathrm{mg} / \mathrm{kg}$ of pentobarbitone was selected for the pentobarbitone-induced sleeping time test that followed.

In this test, groups (VII, VIII and IX) were pre-treated orally with 100,300 or $1000 \mathrm{mg} / \mathrm{kg}$ of TAE after which $50 \mathrm{mg} / \mathrm{kg}$ pentobarbitone sodium was injected intraperitoneally 30 minutes later. The control group (X) initially received distilled water followed by $50 \mathrm{mg} / \mathrm{kg}$ pentobarbitone sodium after 30 minutes. Sleeping time (the period between loss and regain of writhing reflex) of each animal was recorded for statistical analyses.

\section{Sub-acute toxicity test}

Sub-acute toxicity study was conducted following the procedures previously described used. ${ }^{8}$ Male SpragueDawley rats (150-200g) were placed into 4 groups $(n=5)$. Animals in groups I, II and III received 100, 300 or 1000 $\mathrm{mg} / \mathrm{kg}$ (p.o., daily) of TAE respectively for 14 days. The control group (IV) received distilled water. During the period of administration, animals were observed and weighed daily to detect signs of toxicity. All visual observations made were systematically recorded.

\section{Relative organ weights}

After blood collection, animals were sacrificed and their kidney, liver, stomach and spleen were removed, washed and weighed immediately on an electronic balance. Organ-to-body weight ratios were calculated for statistical analysis.

\section{Biochemical assessment}

At the end of the 14 days, blood was collected from the heart (without anticoagulant) into gel separator tubes for biochemical analysis. Serum was separated by centrifugation (1000 $\mathrm{g}$ for 15 minutes). Serum determination of total proteins, total bilirubin, direct bilirubin, indirect bilirubin, albumin, globulin and albumin/globulin $(\mathrm{A} / \mathrm{G})$ ratios were performed using an automated analyser, ATAC 8000 (Elan Diagnostics, CA, USA). Levels of the liver enzymes like alanine aminotransferase (ALT), alkaline phosphatase (ALP), aspartate aminotransferase (AST) and $\gamma$-glutamyl aminotransferase (GGT) were also assessed similarly. 


\section{Haematological assessment}

At the end of the 14 days, the rats were anaesthetized with ether and blood was collected through cardiac puncture into Ethylenediaminetetraaccetic acid (EDTA) tubes. Red blood cells (RBC), white blood cells (WBC), granulocytes, Platelets (PLT), Mean Corpuscular volume (MCV), haematocrit (HCT), Haemoglobin Concentration (HB), Mean Haemoglobin Concentration (MHC) and Mean Corpuscular Haemoglobin Concentration (MCHC) were determined using an automated analyser, Cell Dyne: Model 331430 (Abbott Laboratories, IL, USA).

\section{Statistical analysis}

Data obtained was expressed as mean \pm SEM. Statistical analysis was performed using one-way analysis of variance (ANOVA) followed by Newman-Keuls post hoc test. GraphPad Prism for Windows, Version 5 (GraphPad Software, San Diego, CA, USA) was used for all statistical analyses. Differences between means of treated and control groups were regarded as statistically significant at $P<0.05$.

\section{RESULTS}

\section{Phytochemical screening}

Qualitative phytochemical test indicated that TAE contained alkaloids, tannins, saponins, flavonoids and glycosides.

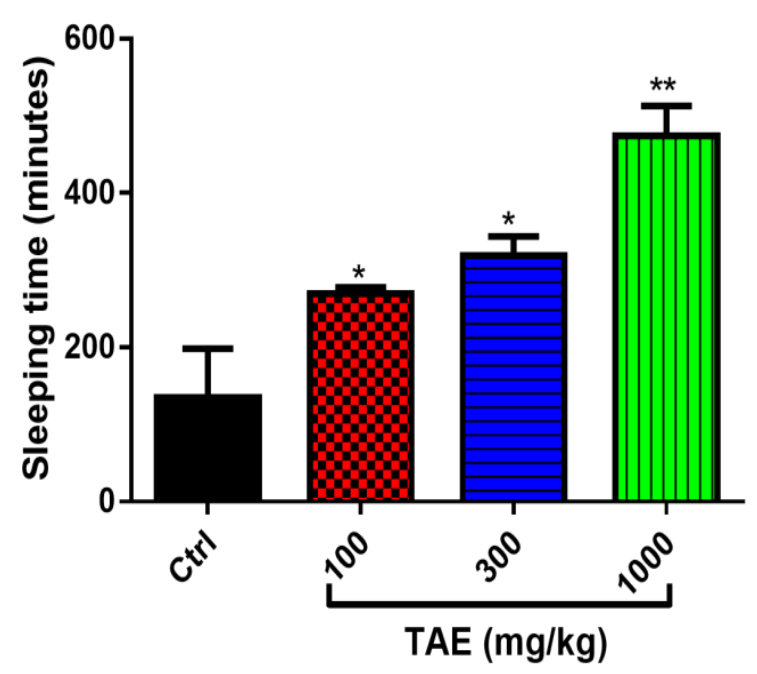

Rats $(n=5)$ were pre-treated with the extract $(100,300$ or 1000 $\mathrm{mg} / \mathrm{kg}$ body weight p.o.) or distilled water 30 minutes before pentobarbitone $(50 \mathrm{mg} / \mathrm{kg}$ i.p. $)$ challenge. Values were expressed as mean \pm SEM. $* * P<0.01 ; * P<0.05$ compared to control (Ctrl) group (1-way ANOVA followed by NewmanKeuls post hoc test).

Figure 1: Effect of TAE on pentobarbitone-induced sleeping time in rats.

\section{Pentobarbitone-induced sleeping test}

From the preliminary test results (unpublished), none of the doses of TAE could cause the animals to sleep within the 90-minute latency period. After the rats were challenged with $50 \mathrm{mg} / \mathrm{kg}$ pentobarbitone sodium, TAE $(100,300$ and $1000 \mathrm{mg} / \mathrm{kg}$ p.o.) caused a significant and dose-dependent increase in sleeping time of rats. The durations of sleep obtained were $269.3 \pm 8.45$ minutes (P $<0.05), 318.7 \pm 25.3$ minutes $(\mathrm{P}<0.05)$ and $473.7 \pm$ 39.25 minutes $(\mathrm{P}<0.01)$ for $100 \mathrm{mg} / \mathrm{kg}, 300 \mathrm{mg} / \mathrm{kg}$ and $1000 \mathrm{mg} / \mathrm{kg}$ of TAE respectively. Rats in control group slept for $135.0 \pm 63.4$ minutes (Figure 1).

Table 1: Effect of TAE on the relative weights of vital organs of rats.

\begin{tabular}{|c|c|c|c|c|}
\hline Dose & $\begin{array}{l}\text { Kidney } \\
(\%)\end{array}$ & $\begin{array}{l}\text { Liver } \\
(\%)\end{array}$ & $\begin{array}{l}\text { Stomach } \\
(\%)\end{array}$ & $\begin{array}{l}\text { Spleen } \\
(\%)\end{array}$ \\
\hline Control & $1.209 \pm 0.28$ & $3.333 \pm 0.51$ & $0.943 \pm 0.51$ & $0.285 \pm 0.03$ \\
\hline $\begin{array}{l}100 \\
\mathrm{mg} / \mathrm{kg}\end{array}$ & $1.011 \pm 0.29$ & $3.147 \pm 0.10$ & $0.920 \pm 0.06$ & $0.326 \pm 0.01$ \\
\hline $\begin{array}{l}300 \\
\mathrm{mg} / \mathrm{kg}\end{array}$ & $1.497 \pm 0.28$ & $3.202 \pm 0.13$ & $1.043 \pm 0.08$ & $0.295 \pm 0.03$ \\
\hline $\begin{array}{l}1000 \\
\mathrm{mg} / \mathrm{kg}\end{array}$ & $1.049 \pm 0.15$ & $3.319 \pm 0.13$ & $0.934 \pm 0.03$ & $0.320 \pm 0.01$ \\
\hline
\end{tabular}

Table 2: Effect of TAE on the levels of AST, ALT, ALP and GGT on rats.

\begin{tabular}{|lllll|} 
Group & $\begin{array}{l}\text { AST } \\
\text { (U/L) }\end{array}$ & $\begin{array}{l}\text { ALT } \\
\text { (U/L) }\end{array}$ & $\begin{array}{l}\text { ALP } \\
\text { (U/L) }\end{array}$ & $\begin{array}{l}\text { GGT } \\
\text { (U/L) }\end{array}$ \\
\hline Control & $6.10 \pm 0.76$ & $17.05 \pm$ & 18.35 & $14.63 \pm$ \\
& & 1.67 & \pm 1.20 & 2.33 \\
\hline $\mathbf{1 0 0}$ & $7.75 \pm 0.84$ & 14.18 & 19.85 & 12.13 \\
$\mathbf{m g} / \mathbf{k g}$ & & \pm 1.96 & \pm 0.41 & \pm 1.64 \\
\hline $\mathbf{3 0 0}$ & $8.47 \pm 0.79$ & 11.55 & 17.70 & $10.55 \pm$ \\
$\mathbf{m g} / \mathbf{k g}$ & & \pm 0.97 & \pm 1.43 & 0.56 \\
\hline $\mathbf{1 0 0 0}$ & $8.90 \pm 2.34$ & 10.80 & 17.83 & 12.13 \\
$\mathbf{m g} / \mathbf{k g}$ & & \pm 1.42 & \pm 2.64 & \pm 1.63 \\
\hline
\end{tabular}

Values are mean \pm S.E.M. $(n=5)$. Treated groups were compared to control group using one-way ANOVA followed by Newman-Keuls post hoc test.

\section{Sub-acute toxicity tests}

Relative organ weights

TAE (100, 300 and $1000 \mathrm{mg} / \mathrm{kg}$ p.o.) administered for 14 days did not cause any significant changes in the relative weights of the organs at all the dose levels tested when compared with control group (Table 1).

\section{Liver enzyme assessment}

TAE (100, 300 or $1000 \mathrm{mg} / \mathrm{kg}$ p.o.) did not induce any significant changes in the levels of AST, ALT, ALP and GGT between the various treated groups when compared to the control group (Table 2). 


\section{Serum protein assessment}

At the end of 14 days of treatment, there were no significant differences $(\mathrm{P}<0.05)$ in any of the serum protein parameters analysed between the control and the TAE-treated groups (Table 3).

Haematological assessment
TAE (100, 300 and $1000 \mathrm{mg} / \mathrm{kg}$ p.o.) did not cause any significant changes in the levels of WBC, RBC, PLT, $\mathrm{HGB}, \mathrm{MCV}, \mathrm{MCH}$ and $\mathrm{MCHC}$ of the rats. At 1000 $\mathrm{mg} / \mathrm{kg}$, all the parameters tested except $\mathrm{MCV}$ and $\mathrm{MCH}$ showed reduced levels compared to the control group. However, the differences were not statistically significant. At $300 \mathrm{mg} / \mathrm{kg}$, all the values except MCHC were insignificantly higher than those of the control group (Table 4).

Table 3: Effect of TAE on blood proteins.

\begin{tabular}{|llllll|}
\hline Dose & $\begin{array}{l}\text { Total protein } \\
\text { (g/dL) }\end{array}$ & $\begin{array}{l}\text { Albumin } \\
\text { (g/dL) }\end{array}$ & $\begin{array}{l}\text { Total bilirubin } \\
\text { (mg/dL) }\end{array}$ & $\begin{array}{l}\text { Direct bilirubin } \\
\text { (mg/dL) }\end{array}$ & $\begin{array}{l}\text { Indirect } \\
\text { bilirubin } \\
\text { (mg/dL) }\end{array}$ \\
\hline Control & $74.78 \pm 1.90$ & $43.83 \pm 1.39$ & $4.68 \pm 0.45$ & $2.18 \pm 0.45$ & $2.50 \pm 0.46$ \\
$\mathbf{1 0 0 ~} \mathbf{~ m g / k g}$ & $72.05 \pm 0.64$ & $43.28 \pm 1.12$ & $4.70 \pm 0.46$ & $2.15 \pm 0.53$ & $2.53 \pm 0.41$ \\
$\mathbf{3 0 0} \mathbf{~ m g / k g}$ & $76.25 \pm 2.62$ & $47.50 \pm 2.07$ & $5.90 \pm 0.69$ & $1.99 \pm 0.68$ & $4.03 \pm 0.57$ \\
$\mathbf{1 0 0 0 ~} \mathbf{~ m g / k g}$ & $72.23 \pm 3.32$ & $42.77 \pm 1.03$ & $4.97 \pm 1.44$ & $1.63 \pm 0.47$ & $3.30 \pm 0.96$ \\
\hline
\end{tabular}

Values are mean \pm S.E.M. $(n=5)$. Treated groups were compared to control group using one-way ANOVA followed by Newman-Keuls post hoc test.

Table 4: Effect of TAE on haematological values of rats.

\begin{tabular}{|c|c|c|c|c|c|c|c|}
\hline Dose & $\begin{array}{l}\text { WBC } \\
\left(\times 10^{9} / L\right)\end{array}$ & $\begin{array}{l}\text { RBC } \\
\left(\times 10^{12} / L\right)\end{array}$ & $\begin{array}{l}\text { PLT } \\
\left(\times 10^{9} / L\right)\end{array}$ & $\begin{array}{l}\text { HGB } \\
\text { (g/dL) }\end{array}$ & $\begin{array}{l}\text { MCV } \\
\text { (fi) }\end{array}$ & $\begin{array}{l}\text { MCH } \\
(\mathbf{p g})\end{array}$ & $\begin{array}{l}\text { MCHC } \\
\text { (g/dL) }\end{array}$ \\
\hline Control & $4.40 \pm 0.34$ & $6.63 \pm 0.29$ & $431.50 \pm 65.96$ & $12.50 \pm 0.84$ & $55.43 \pm 1.45$ & $19.90 \pm 0.25$ & $36.15 \pm 0.52$ \\
\hline 100 mg/kg & $4.23 \pm 0.15$ & $5.88 \pm 0.34$ & $402.50 \pm 78.26$ & $11.80 \pm 0.67$ & $56.80 \pm 0.76$ & $19.93 \pm 0.25$ & $35.18 \pm 0.15$ \\
\hline 300 mg/kg & $4.90 \pm 0.43$ & $6.63 \pm 0.43$ & $440.00 \pm 42.68$ & $13.23 \pm 1.04$ & $56.72 \pm 0.90$ & $20.48 \pm 0.29$ & $35.85 \pm 0.69$ \\
\hline 1000 mg/kg & $4.03 \pm 0.64$ & $6.63 \pm 0.43$ & $369.00 \pm 60.70$ & $11.87 \pm 1.40$ & $55.83 \pm 1.13$ & $20.48 \pm 0.29$ & $35.83 \pm 0.23$ \\
\hline
\end{tabular}

Values are mean \pm S.E.M. $(\mathrm{n}=5)$. Treated groups were compared to control group using one-way ANOVA followed by Newman-Keuls post hoc test.

\section{DISCUSSION}

As reported earlier, petroleum ether, ethyl acetate and hydro-ethanolic extracts of Trichilia monadelpha elicited their analgesic properties through possible mechanisms that involve an interaction with the opioidergic, adenosinergic, muscarinic and ATP-sensitive $\mathrm{K}^{+}$ channels. ${ }^{3}$ In the current study, the aqueous extract exhibited a hypno-sedative effect when it was synergized with pentobarbitone. Pentobarbitone is a barbiturate that produces depressant effect on the central nervous system through activation of gamma aminobutyric acid (GABA) system. ${ }^{9,10}$

In the preliminary test to investigate the intrinsic hypnotic doses of the extract and pentobarbitone, it was observed that $50 \mathrm{mg} / \mathrm{kg}$ pentobarbitone sodium induced sleep in the rats. On the contrary, even the highest dose of the extract $(1000 \mathrm{mg} / \mathrm{kg})$ did not induce sleep in any of the rats tested. However, when the extract was synergized with the sub-hypnotic dose of pentobarbitone sodium, there were significant changes in the duration of sleep in a dose dependent manner. This suggests that the extract at those doses tested did not possess sufficient intrinsic hypnotic effect to cause sleep in the rats. Changes in the duration of pentobarbitone-induced sleeping time in rats is a useful tool for investigating stimulatory or inhibitory effect of centrally-acting compounds especially those that influence the GABAergic system. ${ }^{9-11}$ From the observations made, TAE potentiated the inhibitory effect of pentobarbitone similar to the activities of conventional central nervous depressant drugs. It could be possible that TAE directly or indirectly activated the GABAergic system that culminated in the synergistic effect observed.

In the sub-acute toxicity test, relative organ weights, haematological and biochemical parameters were investigated. Consumption of toxic substances in most cases either increase or decrease the weight of internal vital organs when compared with the total body weight. ${ }^{12,13}$

However, TAE did not alter the relative weights of any of the vital organs studied when compared with control group suggesting it may be non-toxic. Again, lyses of blood cells, inhibition of blood cells synthesis and or 
significant alterations in haematological parameters have been associated with anaemia especially, following the administration of a toxic agent. ${ }^{14,15}$

From our results, TAE did not cause any significant changes in the haematological parameters analysed indicating it may not have toxic effects on the haematological parameters. Moreover, marked changes in the levels of biochemical parameters such as total protein, albumin, bilirubin, AST, ALT, GGT and ALP are used to detect abnormal functioning liver or the presence of hepatocellular damage. ${ }^{16,17}$ Insignificant changes in these parameters compared to control animals suggests TAE (100 -1000 mg/kg) did not cause damage to the liver or changed its normal function.

\section{CONCLUSION}

In this research, TAE (100-1000 $\mathrm{mg} / \mathrm{kg})$ caused significant changes in the duration of sleep in the pentobarbitone-induced sleeping time in rats. TAE however, did not cause any significant changes in relative weights of vital organs, blood components as well as the biochemical parameters.

\section{ACKNOWLEDGEMENT}

We sincerely appreciate the assistance of the entire technical staff of the Department of Pharmacology, School of Pharmacy and Pharmaceutical Sciences, KNUST, Kumasi, Ghana.

Funding: No funding sources

Conflict of interest: None declared

Ethical approval: The study was approved by the Ethics Committee of Department of Pharmacology, School of Pharmacy and Pharmaceutical Sciences, KNUST, Kumasi, Ghana

\section{REFERENCES}

1. Burkill HM. The useful plants of west tropical Africa. Edition 2. Vol. 1: families AD. Kew, Royal Botanic Gardens. 1985.

2. Ainooson G, Owusu G, Woode E, Ansah C, Annan K. Trichilia monadelpha bark extracts inhibit carrageenaninduced foot-oedema in the 7-day old chick and the oedema associated with adjuvant-induced arthritis in rats. Afr J Tradit Complement Altern Med. 2012;9(1):816.

3. Woode E, Amoh-Barimah AK, Abotsi WKM, Ainooson GK, Owusu G. Analgesic effects of stem bark extracts of Trichilia monadelpha (Thonn.) JJ De Wilde. Indian J pharmacol. 2012;44(6):765.

4. Ben I, Woode E, Abotsi W, Boakye-Gyasi E. Preliminary Phytochemical Screening and In vitro Antioxidant Prop-erties of Trichilia monadelpha (Thonn.) JJ de Wilde (Meliaceae). J Med Biomed Sci. 2013;2(2):6-15.

5. Atindehou KK, Schmid C, Brun R, Koné M, Traore D. Antitrypanosomal and antiplasmodial activity of medicinal plants from Côte d'Ivoire. J Ethnopharmacol. 2004;90(2):22127.

6. Trease GE, Evans WC. A Textbook of Pharmacognosy. London: Bailliere Tindall Ltd.; 1989.

7. Sofowora A. Medicinal Plants and Traditional Medicine in Africa. Nigeria: Spectrum Books Ltd.; 1993.

8. Veerappan A, Miyazaki S, Kadarkaraisamy M, Ranganathan D. Acute and subacute toxicity studies of Aegle marmelos Corr., an Indian medicinal plant. Phytomedicine. 2007;14(2):209-15.

9. Ma H, Kim CS, Ma Y, Nam SY, Kim DS, Woo SS, et al. Magnolol enhances pentobarbital-induced sleeping behaviors: possible involvement of GABAergic systems. Phytother Res. 2009;23(9):1340-1344.

10. Ma Y, Han H, Eun JS, Kim HC, Hong JT, Oh KW. Sanjoinine A isolated from Zizyphi Spinosi Semen augments pentobarbital-induced sleeping behaviors through the modification of GABA-ergic systems. Biol Pharma Bull. 2007;30(9):1748-53.

11. Liao JF, Huang SY, Jan YM, Yu LL, Chen CF. Central inhibitory effects of water extract of Acori graminei rhizoma in mice. J Ethnopharmacol. 1998;61(3):185-93.

12. Teo S, Stirling D, Thomas S, Hoberman A, Kiorpes A, Khetani V. A 90-day oral gavage toxicity study of dmethylphenidate and d, 1-methylphenidate in SpragueDawley rats. Toxicology. 2002;179(3):183-96.

13. Murugan R, Vembu T, Kumarswamy M. Toxicological Study of a Siddha Sastric Formulation Arumuga Chendhuram in Rat Model. J App Pharm Sci. 2016;6(03):081-7.

14. Gandhare B, Kavimani S, Rajkapoor B. Acute and subacute toxicity study of methanolic extract of Ceiba pentandra (Linn.) Gaertn. on rats. J Sci Res. 2013;5(2):315-24.

15. Onyeyilli P, Iwuoha C, Akinniyi J. Chronic toxicity study of Ficus platyphtlla blume in rats. West Afr J Pharmacol Drug Res. 1998;14(1).

16. Witthawaskul P, Panthong A, Kanjanapothi D, Taesothikul T, Lertprasertsuke N. Acute and subacute toxicities of the saponin mixture isolated from Schefflera leucantha Viguier. J Ethnopharmacol. 2003;89(1):115-121.

17. El Hilaly J, Israili ZH, Lyoussi B. Acute and chronic toxicological studies of Ajuga iva in experimental animals. J Ethnopharmacol. 2004;91(1):43-50.

Cite this article as: Owusu G, Antwi-Adjei M, Henneh IT. Pentobarbitone-induced sleeping time and sub-acute toxicity studies of Trichilia monadelpha aqueous extract. Int $\mathrm{J}$ Basic Clin Pharmacol 2016;5:2352-6. 